\title{
STATE OF THE SURFACE WATERS IN CROSS BORDER REGION OF EASTERN SERBIA AND CARAS SEVERIN COUNTY - MOLDOVA NOUA IN ROMANIA
}

\author{
ZORAN STEVANOVIĆa*, RENATA KOVAČEVIĆa, \\ RADMILA MARKOVIĆa, VOJKA GARDIĆa, \\ BIANCA CONSTANTINA VULPE ${ }^{\text {bb }}$, BIANCA BOROS ${ }^{b}$, \\ GHEORGHITA MENGHIU
}

\begin{abstract}
Bor, Krivelj, and Bela Rivers in Eastern Serbia belong to the watershed of Timok River, which is a tributary of Danube River. These Rivers flow near to the largest mining complex in Republic of Serbia. Rivers Bosneag, Radimna and Nera from the Romanian side in Caras Severin County near to Moldova Noua are also tributary of Danube and flow in area which is affected by spreading of dust from the abandoned flotation tailing of copper mine. This study includes environmental monitoring of the surface waters in considered Romania-Serbia cross border area during 2019-2020. Chemical analyses confirmed pollution mostly with heavy metals ( $\mathrm{Fe}, \mathrm{Mn}$, $\mathrm{Cu}, \mathrm{Zn}, \mathrm{As}, \mathrm{Ni}, \mathrm{Pb}, \mathrm{Cd}$ ) closer to mines while with larger distance pollution decrease. The measured values were compared with Serbian and Romanian legislation which confirmed moderate and high pollution depending on category of surface waters. Measured Cd concentrations were of $9.51-5375 \mu \mathrm{g} \mathrm{L}^{-1}$ for the IV category of River water close to Bor mine. The main anthropogenic source in Eastern Serbia was Bor mine and smelter.
\end{abstract}

Keywords: mining, surface waters, tailings, monitoring, pollution

\section{INTRODUCTION}

Mining is one of the oldest industrial activities. The huge amounts of tailings that are created during the extraction and processing of ore represent a great danger to the environment and destroy agricultural land and forests.

a Mining and Metallurgy Institute Bor, Zeleni bulevar 35, 19210 Bor, Serbia

b West University of Timisoara, Faculty of Chemistry, Biology, Geographic, Department of Biology-Chemistry, Oitz 4A, Timisoara, Romania

* Corresponding author: zoran.stevanovic@irmbor.co.rs 
The dust that the wind disperses from the tailings represent environment hazard by pollution of heavy metals ions. Tailings are also a source of Acid Mine Drainages (AMD) that contains high concentrations of metal cations, especially iron, and often toxic chemical elements such as arsenic [1]. AMD are one of the most significant environmental risks globally because they could be transported by surface waters on wider area, sometimes even out of the country. Hundreds of thousands of hectares of land and thousands of kilometers of watercourses around the world are threatened by the runoff of AMD [2]. Abandoned mines and tailings can generate acidic water for tens, hundreds, even thousands of years. Abandoned Richmond pyrite mine in California (USA) is estimated to generate an extremely acidic solution for the next 3,000 years [3], while a small zinc and copper mine in northwestern Ontario (Canada) is estimated to generate acidic mine waters in the next $10,000-35,000$ years [4]. Although these are extreme examples, it is not uncommon for abandoned mine shafts and tailings to have the capacity to form acidic solutions over a period of hundreds of years. Surface and underground ore mining generally have serious negative impacts on the environment such as air pollution, land use and biodiversity and water availability. Also, some effluents generated in the mining industry contain large amounts of toxic substances (cyanides, heavy metals and other harmful and dangerous substances), which have serious human health and environmental hazards [5-7]. Based on possible hazards, waste mine water generated from active as well as abandoned mines is one of the main chemical threats to groundwater and surface water.

According to a study prepared for DG Environment, the European Commission, more than 4.7 billion tons of mining waste and 1.2 billion tons of flotation tailings were disposed of across the European Union [8]. Ten thousand active and abandoned mines are source for $5-10 \times 10^{9} \mathrm{~m}^{3}$ of highly polluted AMD annually [9]. Global mining activities with technological processes of mineral processing and metal production generate several billion tons of solid inorganic waste or by-products, including liquid waste [10]. Balkan Peninsula was generally the main area in Europe for supply of copper, lead and zinc until 1990 [11] and many mines still are operational. Also, in this area exist and many abandoned mines and tailings which represent continuous environmental threat. Some previous environmental assessments on Balkan Peninsula show high mining impact on surface waters with coupling of findings from the natural science and socioeconomic approaches [12].

Due to a great negative impact of mining industry on water system, the aim of cross-border collaborative project (ROSNET2) was to perform the monitoring of surface waters close to active and abandoned mines in cross border area. 
This paper includes results of environmental monitoring of the surface waters quality in considered Romania-Serbia cross border area during 20192020. The main objective was providing of timely response and warning for possible negative processes and accident situations and gain a complete insight into the state of the surface waters in Project area. All the results will be systematized and grouped in data base with updating possibility with new data and available to interested public.

\section{RESULTS AND DISCUSSION}

In Serbia, the most important copper mines are located in Eastern Serbia in Bor District. There are two mines with open pit exploitation (Veliki Krivelj and Cerovo), one undergrounds mine (Jama mine), two mineral processing plants in Krivelj and Bor and smelter for Cu concentrate. Certified geological reserves amount to approximately 3 billion tons of ore and they contain approximately 12 million tons of $\mathrm{Cu}$. Confirmed reserves, with the average annual exploitation, guarantee copper production for the next 100 years. Long mining history resulted that in the immediate vicinity of Bor, exist huge quantities of open pit overburden and flotation tailings ( $>2$ billion tons) which contain hazardous and dangerous materials such as copper, nickel, arsenic, zinc, antimony, mercury, chromium, bismuth [13]. Waste Management Strategy of the Republic of Serbia for the Period 2010-2019 illustrates that 40000 ha of soil is polluted by mining operation, $7 \%$ being situated in Bor Region. Most of copper production of Serbia is located in Eastern Serbia and the total polluted surface of soil is 2784 ha. During the period 1933-1970, the flotation tailing completely degraded the valley of the Bor River which flows through the village near the Bor. Entire length of the Bor River flow to the empties into the Krivelj River, about 70 hectares of coastal land was polluted by the flotation tailings. It is estimated that the flotation tailings polluted even more than 2000 ha of the most fertile coastal land of the above rivers. In addition to the physical contamination of the coastal land of the Bor River valley by thousands of tons of flotation tailings, the Bor River is constantly polluted by waste water resulting from draining through the flotation tailings and open pit overburden [11].

Moldova Nouă is the second largest copper reserve in Romania (500 million tons of ore grading $0.35 \%$ copper) [14] and also the largest in considered cross border area. The operations were stopped but the environmental damages are still present. The tailings ponds from Moldova Nouă contain approximately 30 million $\mathrm{m}^{3}$ of tailings covering an area of 130 ha with a height of most tan 20 meters [15]. One of the worst cases is represented by Tăuşani-Boşneag pond placed between Moldova Veche 
town and Coronini village, Caraş-Severin County. Annual report concerning the state of the environment in Romania for 2019 illustrates that 24432 ha of soil are polluted by mining operations and 6639 ha of soil are polluted by heaps, tailings ponds, sterile deposits from floating and warehouses waste. The largest surfaces with polluted soil $(23.2 \%)$ are registered in the area of the mines situated in the cross-border region of Romania and Serbia. The same report exposes the soil pollution affects about 0.9 million ha, the most destructive being the pollution with heavy metals $(\mathrm{Cu}, \mathrm{Pb}, \mathrm{Zn}, \mathrm{Cd})$ and sulphur dioxide. Additionally, the soil pollution with particles carried by the wind affects 0.363 million ha.

Flotation tailings are one of the sources for dust and AMD pollution. Two examples from both side of border (Tăuşani-Boşneag pond near Moldova Noua in Romania and old Bor flotation tailing in Bor) are presented in Figure 1.

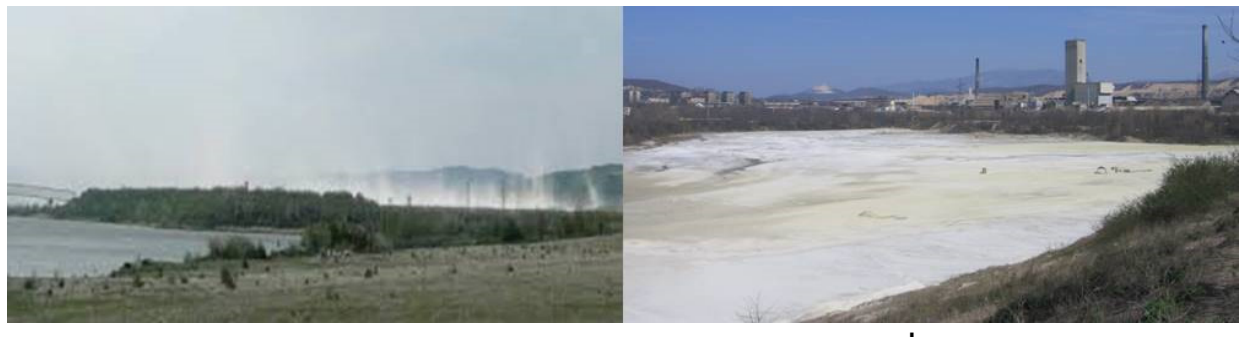

a

$b$

Figure 1. a) Tăuşani-Boşneag pond near Moldova Noua in Romania in windy conditions; b) Old Bor flotation tailing in Bor River valley

One type of pollution caused by flotation tailing is spreading of dust. Figure 1a shows spreading of the dust from the tailing in windy conditions. This dust usually contains small particles with heavy metal content which could be easily transferred into soil or surface waters and transported far away from the tailing. Both of presented mines are copper mines, where copper is in association with sulphur, iron, carbon and oxygen. In Serbia and Romania, copper mineralization is mostly porphyry type of deposits containing mostly sulphur minerals associated with pyrites that are one of the main sulfuric acid generators in contact with atmospheric precipitations. Consequently, Acid Mine Drainages generated from those kinds of waste materials is one of the main chemical threats to groundwater and surface water quality. AMD are, as a rule, acidic with $\mathrm{pH}$ value mostly between 2.5 and 4 due to an elevated concentration of sulphuric acid, as a second product of bacterial oxidation of sulphide minerals. Pyrite is the most abundant mineral in polymetallic sulphide ore deposits and in mining waste dumps. The oxidation of 
pyrite and copper minerals in an aqueous environment occurs via two simultaneous mechanisms, i.e., biochemical involving bacteria, and chemical way, can be described by the following stoichiometric reactions [16-18]:

(Bacterial)

$$
\begin{aligned}
& 2 \mathrm{FeS}_{2}+7.5 \mathrm{O}_{2}+\mathrm{H}_{2} \mathrm{O} \rightarrow \mathrm{Fe}_{2}\left(\mathrm{SO}_{4}\right)_{3}+\mathrm{H}_{2} \mathrm{SO}_{4} \\
& 2 \mathrm{FeS}_{2}+7 \mathrm{Fe}_{2}\left(\mathrm{SO}_{4}\right)_{3}+8 \mathrm{H}_{2} \mathrm{O} \rightarrow 15 \mathrm{FeSO}_{4}+8 \mathrm{SO}_{4} \\
& \mathrm{FeS}_{2}+\mathrm{Fe}_{2}\left(\mathrm{SO}_{4}\right)_{3} \rightarrow 3 \mathrm{FeSO}_{4}+2 \mathrm{~S}^{0} \\
& \mathrm{~S}^{0}+\mathrm{H}_{2} \mathrm{O}+1.5 \mathrm{O}_{2} \rightarrow \mathrm{H}_{2} \mathrm{SO}_{4}
\end{aligned}
$$

Based on composition, heavy metal ions mobilization, surface water transportation on wider area and capacity of mine for generation, release of AMD that contained elevated concentrations of metals from mine wastes induces an environmental problem of global scale. The UN has even labelled AMD as the second biggest problem facing the world after global warming. in Figure 2.

Locations of surface water sampling in Eastern Serbia are presented

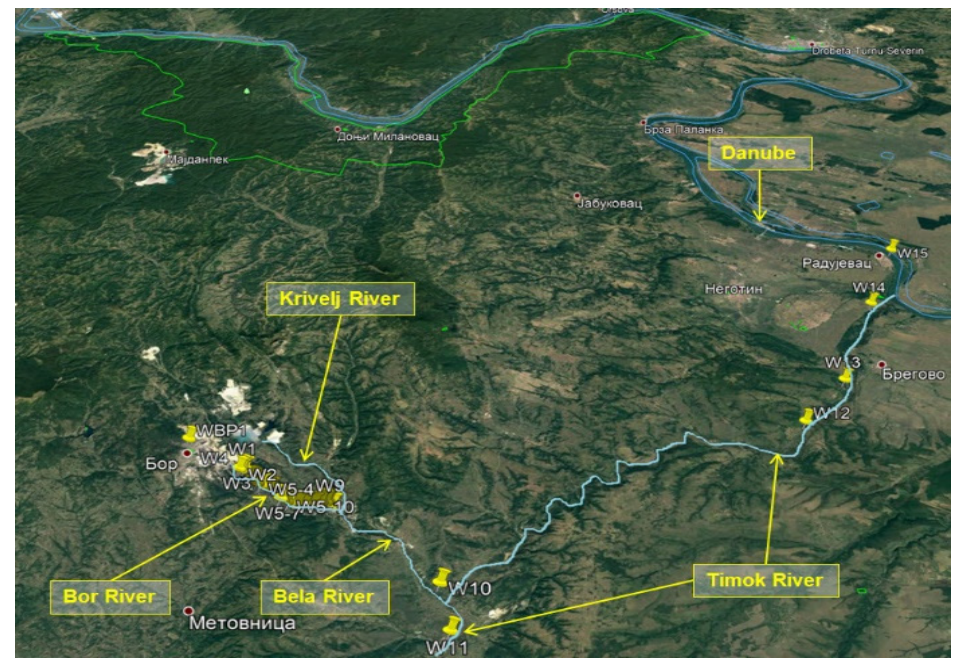

Figure 2. Surface water sampling - Eastern Serbia side

Locations of surface water samples are: (W1, W2) Robule accumulation; (W3) AMD from flotation tailing dam "RTH"; (W4) Industrial wastewater; (14 samples W5-1 - W5-14) Bor River before confluence with Krivelj River; (W6) Krivelj River, (W7) Bela River after the confluence of Bor and Krivelj River, (W8) Ravna River, (W9) Bela River after flows of Ravna River; (W10) Bela River before of confluence in Timok River; (W11) Timok River before confluence of Bela River; (W12) Timok River after confluence of Bela River (Rajac); (W13) Timok River (Mokranje-Negotin); (W14) Timok River (Bukovce); (W15) Danube River (Radujevac). 
The results of chemical analyses of surface waters from the Serbian side and Maximum Allowed Concentrations (MAC) according to Serbian legislative are presented in Table 1.

Table 1. Chemical analyses of surface waters from the Serbian side

\begin{tabular}{|c|c|c|c|c|c|}
\hline $\begin{array}{c}\text { Category of } \\
\text { surface water / } \\
\text { Location }\end{array}$ & Parameter & $\begin{array}{c}\text { Range } \\
\text { (min-max) }\end{array}$ & Median & MAC & $\begin{array}{c}\text { Content } \\
>\text { MAC }(\%)^{1}\end{array}$ \\
\hline \multirow{11}{*}{$\begin{array}{c}\text { IV } \\
\text { From Bor city to } \\
\text { the confluence } \\
\text { Bor and Timok } \\
\text { River } \\
\text { Samples } \\
(\mathrm{W} 1-\mathrm{W} 10)\end{array}$} & $\mathrm{Fe}\left(\mathrm{mg} \mathrm{L}^{-1}\right)$ & $0.069-1231$ & 134.9 & 2 & 96 \\
\hline & $\mathrm{Mn}\left(\mathrm{mg} \mathrm{L}^{-1}\right)$ & $1.8-115.8$ & 5.9 & 1 & 100 \\
\hline & $\mathrm{Cu}\left(\mathrm{mg} \mathrm{L}^{-1}\right)$ & $0.089-318.7$ & 50.6 & 1 & 98 \\
\hline & $\mathrm{Zn}\left(\mathrm{mg} \mathrm{L}^{-1}\right)$ & $0.28-43.2$ & 7.5 & 5 & 88 \\
\hline & As $\left(\mu \mathrm{g} \mathrm{L}^{-1}\right)$ & $<2.1-25058$ & 385.4 & 100 & 72 \\
\hline & $\mathrm{Ni}\left(\mu \mathrm{g} \mathrm{L}^{-1}\right)$ & $7-16200$ & 992 & 34 & 91 \\
\hline & $\mathrm{Pb}\left(\mu \mathrm{g} \mathrm{L}^{-1}\right)$ & $<2.1-3718$ & 493 & 14 & 83 \\
\hline & $\mathrm{Cd}\left(\mu \mathrm{g} \mathrm{L}^{-1}\right)$ & $9.51-5375$ & 715.8 & 0.9 & 100 \\
\hline & $\mathrm{Cr}\left(\mathrm{mg} \mathrm{L}^{-1}\right)$ & $<0.005-0.14$ & 0.020 & 0.25 & 0 \\
\hline & $\mathrm{Hg}\left(\mu \mathrm{g} \mathrm{L}^{-1}\right)$ & $<0.5$ & $<0.5$ & 0.3 & 0 \\
\hline & $\mathrm{SO}_{4}^{2-}\left(\mathrm{mg} \mathrm{L}^{-1}\right)$ & $1246-13964$ & 2179.0 & 300 & 100 \\
\hline \multirow{11}{*}{$\begin{array}{c}\text { III } \\
\text { From the } \\
\text { confluence Bor } \\
\text { and Timok River } \\
\text { up to the } \\
\text { confluence of } \\
\text { Timok and } \\
\text { Danube River } \\
\text { Samples } \\
\text { (W12-W14) }\end{array}$} & $\mathrm{Fe}\left(\mathrm{mg} \mathrm{L}^{-1}\right)$ & $<0.007-0.16$ & 0.034 & 1 & 0 \\
\hline & $M n\left(m g ~ L^{-1}\right)$ & $<0.006-0.78$ & 0.47 & 0.3 & 50 \\
\hline & $\mathrm{Cu}\left(\mathrm{mg} \mathrm{L}^{-1}\right)$ & $<0.005-0.33$ & 0.064 & 0.5 & 0 \\
\hline & $\mathrm{Zn}\left(\mathrm{mg} \mathrm{L}^{-1}\right)$ & $<0.005-0.76$ & 0.30 & 2 & 0 \\
\hline & As $\left(\mu \mathrm{g} \mathrm{L}^{-1}\right)$ & $<2.1-4.4$ & 3.62 & 50 & 0 \\
\hline & $\mathrm{Ni}\left(\mu \mathrm{g} \mathrm{L}^{-1}\right)$ & $7-1600$ & 362 & 34 & 67 \\
\hline & $\mathrm{Pb}\left(\mu \mathrm{g} \mathrm{L}^{-1}\right)$ & $<2.1-5.9$ & 5.9 & 14 & 0 \\
\hline & $\mathrm{Cd}\left(\mu \mathrm{g} \mathrm{L}^{-1}\right)$ & $<1.1-47.0$ & 25.8 & 0.6 & 58 \\
\hline & $\mathrm{Cr}\left(\mathrm{mg} \mathrm{L}^{-1}\right)$ & $<0.005$ & - & 0.1 & 0 \\
\hline & $\mathrm{Hg}\left(\mu \mathrm{g} \mathrm{L}^{-1}\right)$ & $<0.5$ & $<0.5$ & 0.3 & 0 \\
\hline & $\mathrm{SO}_{4}^{2-}\left(\mathrm{mg} \mathrm{L}^{-1}\right)$ & $82.2-691.6$ & 270.6 & 200 & 50 \\
\hline \multirow{11}{*}{$\begin{array}{c}\text { II } \\
\text { Danube } \\
\text { Sample } \\
\text { (W15) }\end{array}$} & $\mathrm{Fe}\left(\mathrm{mg} \mathrm{L}^{-1}\right)$ & $<0.007-0.34$ & 0.011 & 0.5 & 0 \\
\hline & $\mathrm{Mn}\left(\mathrm{mg} \mathrm{L}^{-1}\right)$ & $<0.006-1.6$ & 0.33 & 0.1 & 5 \\
\hline & $\mathrm{Cu}\left(\mathrm{mg} \mathrm{L}^{-1}\right)$ & $<0.005-0.48$ & 0.025 & 0.1 & 0 \\
\hline & $\mathrm{Zn}\left(\mathrm{mg} \mathrm{L}^{-1}\right)$ & $<0.005-0.037$ & 0.037 & $0.3-2$ & 0 \\
\hline & As $\left(\mu \mathrm{g} \mathrm{L}^{-1}\right)$ & $<2.1-14.8$ & 4.8 & 10 & 15 \\
\hline & $\mathrm{Ni}\left(\mu \mathrm{g} \mathrm{L}^{-1}\right)$ & $7-74$ & 62 & 34 & 30 \\
\hline & $\mathrm{Pb}\left(\mu \mathrm{g} \mathrm{L}^{-1}\right)$ & $<2.1-5.5$ & 5.5 & 14 & 0 \\
\hline & $\mathrm{Cd}\left(\mu \mathrm{g} \mathrm{L}^{-1}\right)$ & $<0.14-0.78$ & 0.20 & 0.45 & 5 \\
\hline & $\mathrm{Cr}\left(\mathrm{mg} \mathrm{L}^{-1}\right)$ & $<0.005$ & - & 0.05 & 0 \\
\hline & $\mathrm{Hg}\left(\mu \mathrm{g} \mathrm{L}^{-1}\right)$ & $<0.5$ & $<0.5$ & 0.3 & 0 \\
\hline & $\mathrm{SO}_{4}^{2-}\left(\mathrm{mg} \mathrm{L}^{-1}\right)$ & $26.7-1950$ & 60.4 & 100 & 40 \\
\hline
\end{tabular}

(1)Content $>$ MAC (\%) represent the percentage value of the number of the samples from the total number of taken samples that had measured values over MAC. 
In Eastern Serbia, pH values for surface water samples from Bor city to the confluence of Bor and Timok River range from 1.77 to 7.72 indicating that most of the analyzed surface waters are strong acid water with $\mathrm{pH}$ values lower than $3.0[19,20]$. According to Serbian legislation for surface water, in rivers from Bor city to the confluence Bor and Timok (IV water category), the content for almost all of the analyzed elements and sulfate are above the MAC [21].

Surface waters from Bor mining complex up to confluence with Timok River are extremely enriched with toxic elements such as arsenic and cadmium [22]. The manganese and cadmium concentrations in surface water samples from this area were above the MAC in all analysed samples $(100 \%>M A C)$ as well as sulphate content. Exceedances of MAC values in these surface waters in a high percentage, above $70 \%$, were also recorded for $\mathrm{Cu}(98.84 \%), \mathrm{Fe}(96.51 \%), \mathrm{Ni}(91.86 \%), \mathrm{Zn}(88.37 \%), \mathrm{Pb}(83.72 \%)$ and As $(72.09 \%)$. The only element with content below the MAC is chromium. As particular concern is the data for cadmium, the maximum detected value of this highly toxic metal is almost 5500 times higher than the MAC. Fe was the most abundant element in IV class of surface water samples with median value of $134 \mathrm{mg} \mathrm{L}^{-1}$ and concentrations in range from 0.069 to $1231 \mathrm{mg} \mathrm{L}^{-1}$.

The Median value $[23,24]$ is presented to indicate the central tendency of these highly scattered data. High presence of copper in IV class of surface water is also recorded with median value of $385.4 \mathrm{mg} \mathrm{L}^{-1}$ and concentration range from 0.089 to $318.7 \mathrm{mg} \mathrm{L}^{-1}$. Considering recorded content, median value and percentage of samples with higher content than MAC, pollution main hazards are $\mathrm{Cd}, \mathrm{Mn}, \mathrm{Cu}, \mathrm{Fe}, \mathrm{Ni}, \mathrm{Zn}, \mathrm{Pb}$ and $\mathrm{As}$. However, with addition consideration on pollutants impact on human health, the main risk is caused by $\mathrm{Cd}, \mathrm{As}, \mathrm{Pb}$ and $\mathrm{Cu}$ pollution. One of the highest pollution hazards represents Cadmium (Cd) with maximum recorded value of $5375 \mu \mathrm{g} \mathrm{L}^{-1}$ which is more than 5500 times higher than allowed concentration. Cd is a toxic heavy metal and its chronic exposure leads to antagonistic changes in living organisms when it enters the food chain [25]. It has gained the attention of scientists after a breakout of Itai-Itai disease in Japan that resulted from wastewater irrigation of agricultural lands [26]. In humans, Cd main intake occurs through food intake and once entered the human body $\mathrm{Cd}$ accumulates to a high level in several organs [27]. Cd is usually associated with chronic kidney disease, osteoporosis, diabetes, cardiovascular disease and cancer from long term exposure at levels above the MAC [28, 29]. Mining activity is one of the predominant sources of Arsenic (As) pollution. As is also extremely high pollution hazard with recorded $72.09 \%$ of samples with increased values than MAC. Maximum recorded As value is more than 250 times higher than MAC. Arsenic is highly carcinogenic in waters [30], classified 
by U.S. EPA as a Group A human carcinogen [31] and may cause serious diseases to humans $[32,33]$. Lead $(\mathrm{Pb})$ is the most toxic element that is present in the environment as a result of both natural and anthropogenic sources [34]. In case of Bor surrounding surface water the main source is, like for the other pollutants, huge mining activities. Pb was recorded in 83.72 $\%$ of samples with increased values than MAC with maximum recorded value of also more than 250 times higher than MAC. The primarily routes of lead exposure are through ingestion and inhalation. Once absorbed, lead binds to erythrocytes and travels in the blood to various tissues (liver, kidneys, lungs, brain, spleen, muscles, and heart) and moves further into bones and teeth, and may affect any organ or system in the body through fundamental biochemical processes [35, 36]. Even at low concentration, it can induce neurobehavioral dysfunctions, anaemia, cardiac dysfunction and vascular damage, kidney diseases, reproductive effects, bone toxicity and alters the major cellular functions [37-42]. Copper $(\mathrm{Cu})$ is a most expected pollutant in Bor surrounding surface waters due to more than 115 years long history of copper mining in this area. Cu was recorded in $98.84 \%$ of samples with increased values than MAC with maximum recorded value of more than 300 times higher than MAC. Human exposure to copper is similar to other metal ions, $\mathrm{Cu}$ being ingested with vegetables that extract it from soil solution via roots or by contaminated water and via the inhalation of particulate matter. Concerning human health, the toxicity of $\mathrm{Cu}$ is relatively low compared with other heavy metals, but excess copper accumulation in subjects following high-dose chronic exposure and in sensitive population's results in hepatic cirrhosis with jaundice, haemolytic anaemia, and degeneration of the basal ganglia, cardio toxicity, gastrointestinal disorders and central nervous system manifestations [43].

Samples from surface waters from rivers that belong to the III category (from the confluence Bor and Timok River to the confluence of Timok and Danube River) show that most of the elements and sulfates are below the MAC for the given category of surface waters. The manganese and sulphate content was exceeded in half of the analysed samples. The content of nickel and cadmium for this category of surface waters was exceeded in $66.67 \%$ and $58.33 \%$ of the analysed samples, respectively. The recorded concentrations of other considered elements were below the MAC values for this category of surface waters. Content of the main heavy metal polluter were dropped by increasing of distance from mining complex and by mixing of Bela River with Timok River. However, even in these surface waters, Cd was recorded with maximum concentration of over 70 times and median value of over 40 times higher than MAC for this category of surface waters. Nickel was recorded with maximum concentration of over 47 times and median value of over 10 
times higher than MAC while manganese was recorded with maximum concentration of over 2 times and median value slightly higher than MAC.

The situation is even better with II category surface waters (Danube River) in which increased values of manganese and cadmium in $5 \%$, arsenic in $15 \%$, nickel in $30 \%$ and sulphate in $40 \%$ of the analysed samples were detected. Unlike IV class of surface waters, the maximum detected values of individual elements in II class of surface waters are not more than 2 times the MAC values.

Figure 3 illustrate as example trends of elements measured in higher concentrations $(\mathrm{mg} / \mathrm{l})$.

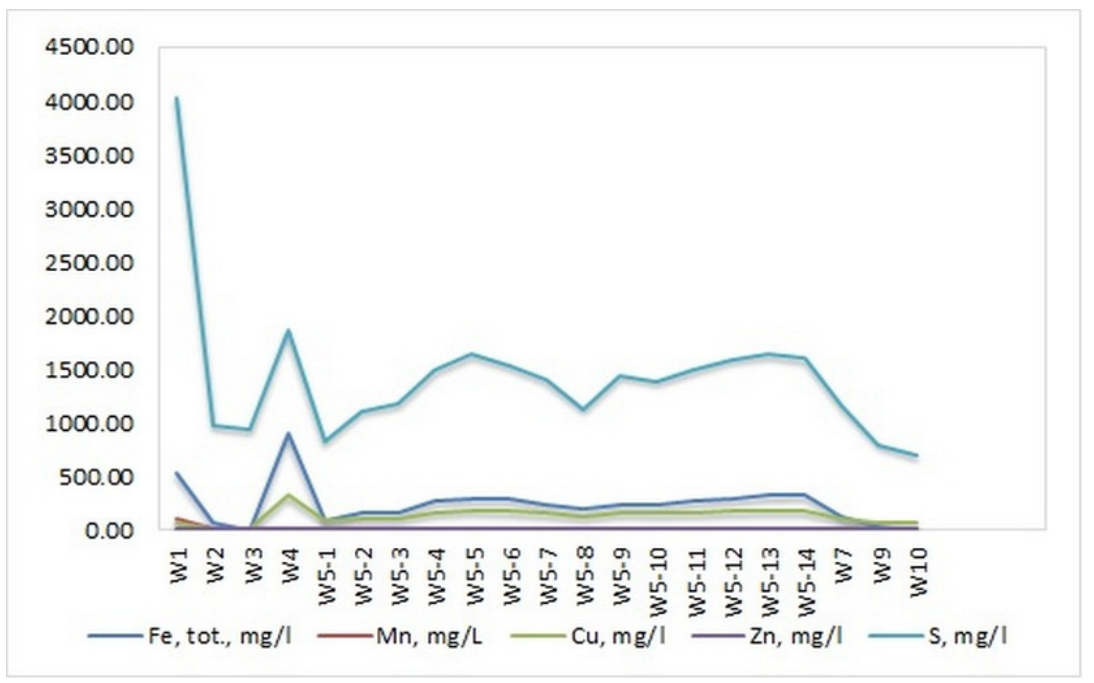

Figure 3. Trends of elements with higher concentrations - Eastern Serbia side

As it could be seen from the plot in Figure 3, pollutants show similar zigzag pattern, high concentrations of one species correspond to high concentrations of other species. These species show strong correlation indicating as the main source of pollution Bor mine and smelter [44, 45]. In addition, the relationships between species (Figure 4 - example for copper and zinc) were examined to evaluate relationships between the species that may indicate a common source. 


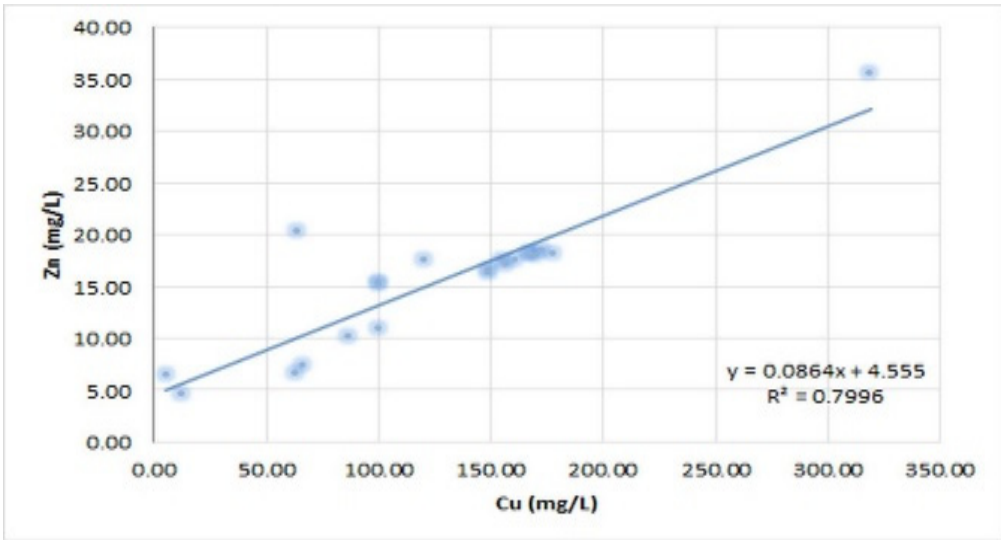

Figure 4. $\mathrm{Cu}$ and $\mathrm{Zn}$ concentrations relations - Eastern Serbia side

According to the scatter plot results, the coefficient of determination $\left(R^{2}=0.7996\right)$ shows that almost $80 \%$ of concentrations of copper are well correlated with concentrations of zinc confirming the same anthropogenic source of pollution for this species. This may indicate that heavy metals in surface waters of III and IV category were originated from a single anthropogenic source of pollution. In case of Eastern Serbia, a copper smelter was the main source.

Figure 5 illustrate as example trends of elements measured in lower absolute concentrations $(\mu \mathrm{g} / \mathrm{l})$.

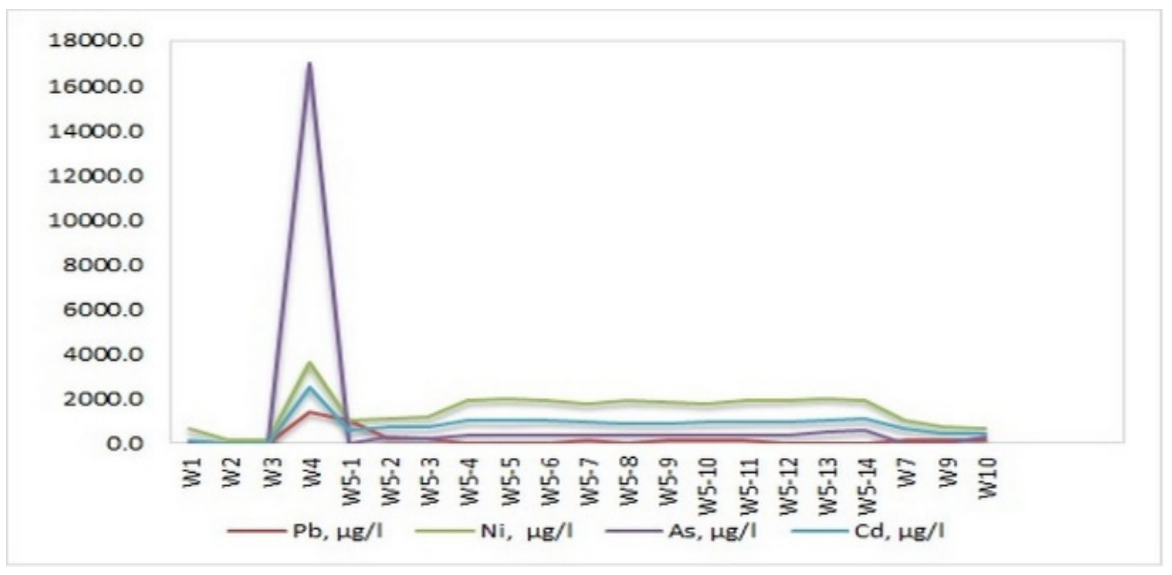

Figure 5. Trends of elements with lower absolute concentrations - Eastern Serbia 
Heavy pollutants shown in Figure 5, with lower absolute concentrations but all above MAC values, show similar zigzag pattern like pollutants in Figure 3 indicating the single and common source of pollution.

Locations of surface water sampling in Caras Severin County near Moldova Noua in Romania are presented in Figure 6. Having on mind that copper mine from Romanian side is not in operational stage, water samples were taken for monitoring purposes at first. Sampling locations were chosen to cover surface waters in surrounding area where could be expected pollution by spreading of dust from the abandoned flotation tailing. Sequence of sampling was scheduled to cover different weather condition and seasons.

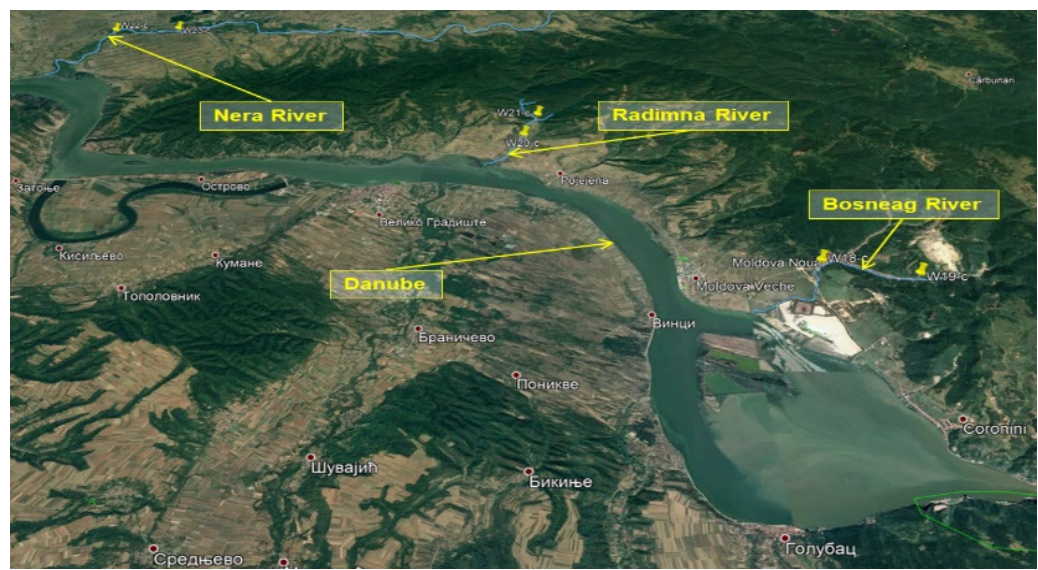

Figure 6. Surface water sampling - Romanian side

Locations of surface water samples are: (W18-c, W19-c) Bosneag River, Moldova Veche and upstream Moldova Veche; (W20-c, W21-c) Radimna River, Pojejena and upstream Pojejena; (W22-c, W23-c) Nera River, Socol and upstream Socol. Considered rivers from Romanian side cannot be polluted by AMD because they do not have direct contact with tailing material and they are not on downstream of possible AMD leaking from tailing but they can indicate pollution by spreading of dust from the tailing. This objective was chosen because of heavy spreading of dust from the abandoned tailing due to strong winds in this area.

The results of chemical analyses of surface waters from the Romanian side and MAC according to Romanian legislative [46] are presented in Table 2. All the results from the monitoring in scope of ROSNET2 are also available in created Knowledgebase [47]. 
Considered rivers in Caras Severin County near Moldova Noua in Romania mostly do not have acidic characteristics except slightly increased value than MAC for Bosneag River. This increased value $\left(133.7 \mathrm{mg} \mathrm{L}^{-1}\right)$ is actually small and could not be stated as significant acidic characteristic. Probable reason for this value is vicinity of Bosneag River to flotation tailing.

Table 2. Chemical analyses of surface waters from the Romanian side

\begin{tabular}{|c|c|c|c|c|c|}
\hline \begin{tabular}{|c|}
$\begin{array}{c}\text { Category of } \\
\text { surface water } \\
\text { / Location }\end{array}$ \\
\end{tabular} & Parameter & $\begin{array}{c}\text { Range } \\
\text { (min-max) }\end{array}$ & Median & MAC & $\begin{array}{c}\text { Content } \\
>\text { MAC (\%) }\end{array}$ \\
\hline \multirow{11}{*}{$\begin{array}{c}\text { II } \\
\text { Bosneag River } \\
\text { Samples } \\
\text { (W18c-W19c) }\end{array}$} & $\mathrm{Fe}\left(\mathrm{mg} \mathrm{L}^{-1}\right)$ & $0.0087-0.8903$ & 0.4782 & 0.5 & 50 \\
\hline & $\mathrm{Mn}\left(\mathrm{mg} \mathrm{L}^{-1}\right)$ & $<0.0016-0.0583$ & 0.0583 & 0.1 & 0 \\
\hline & $\mathrm{Cu}\left(\mathrm{mg} \mathrm{L}^{-1}\right)$ & $0.0284-0.1158$ & 0.069 & 0.03 & 75 \\
\hline & $\mathrm{Zn}\left(\mathrm{mg} \mathrm{L}^{-1}\right)$ & $0.0252-0.0549$ & 0.0472 & 0.2 & 0 \\
\hline & As $\left(\mu \mathrm{g} \mathrm{L}^{-1}\right)$ & $<2.1-3.7$ & 3.0 & 20 & 0 \\
\hline & $\mathrm{Ni}\left(\mu \mathrm{g} \mathrm{L}^{-1}\right)$ & $<3.6-4.2$ & 4.2 & 25 & 0 \\
\hline & $\mathrm{Pb}\left(\mu \mathrm{g} \mathrm{L}^{-1}\right)$ & $<2.1-3.7$ & 3.7 & 10 & 0 \\
\hline & $\mathrm{Cd}\left(\mu \mathrm{g} \mathrm{L}^{-1}\right)$ & $<0.14-0.39$ & 0.26 & 1 & 0 \\
\hline & $\mathrm{Cr}\left(\mathrm{mg} \mathrm{L}^{-1}\right)$ & $<0.0017$ & 1 & 0.05 & 0 \\
\hline & $\mathrm{Hg}\left(\mu \mathrm{g} \mathrm{L}^{-1}\right)$ & $<0.5$ & $<0.5$ & 0.3 & 0 \\
\hline & $\mathrm{SO}_{4}^{2-}\left(\mathrm{mg} \mathrm{L}^{-1}\right)$ & $78.5-295.8$ & 133.7 & 120 & 50 \\
\hline \multirow{11}{*}{$\begin{array}{c}\text { II } \\
\text { Radimna River } \\
\text { Samples } \\
\text { (W20c- } \\
\text { W21c) }\end{array}$} & $\mathrm{Fe}\left(\mathrm{mg} \mathrm{L}^{-1}\right)$ & $0.1310-0.2652$ & 0.2397 & 0.5 & 0 \\
\hline & $\mathrm{Mn}\left(\mathrm{mg} \mathrm{L}^{-1}\right)$ & $0.0106-0.0326$ & 0.0230 & 0.1 & 0 \\
\hline & $\mathrm{Cu}\left(\mathrm{mg} \mathrm{L}^{-1}\right)$ & $0.0376-0.0546$ & 0.0474 & 0.03 & 100 \\
\hline & $\mathrm{Zn}\left(\mathrm{mg} \mathrm{L}^{-1}\right)$ & $0.0176-0.0333$ & 0.0216 & 0.2 & 0 \\
\hline & As $\left(\mu g \mathrm{~L}^{-1}\right)$ & $<2.1$ & 1 & 20 & 0 \\
\hline & $\mathrm{Ni}\left(\mu \mathrm{g} \mathrm{L}^{-1}\right)$ & $<3.6$ & 1 & 25 & 0 \\
\hline & $\mathrm{Pb}\left(\mu \mathrm{g} \mathrm{L}^{-1}\right)$ & $<2.1$ & l & 10 & 0 \\
\hline & $\mathrm{Cd}\left(\mu \mathrm{g} \mathrm{L}^{-1}\right)$ & $<0.14$ & I & 1 & 0 \\
\hline & $\mathrm{Cr}\left(\mathrm{mg} \mathrm{L}^{-1}\right)$ & $<0.0017$ & 1 & 0.05 & 0 \\
\hline & $\mathrm{Hg}\left(\mu \mathrm{g} \mathrm{L}^{-1}\right)$ & $<0.5$ & $<0.5$ & 0.3 & 0 \\
\hline & $\mathrm{SO}_{4}^{2-}\left(\mathrm{mg} \mathrm{L}^{-1}\right)$ & $21.9-30.3$ & 24.8 & 120 & 0 \\
\hline \multirow{11}{*}{$\begin{array}{c}\text { II } \\
\text { Nera River } \\
\text { Samples } \\
\text { (W22c-W23c) }\end{array}$} & $\mathrm{Fe}\left(\mathrm{mg} \mathrm{L}^{-1}\right)$ & $0.9895-1.1643$ & 1.0292 & 0.5 & 100 \\
\hline & $\mathrm{Mn}\left(\mathrm{mg} \mathrm{L}^{-1}\right)$ & $0.0423-0.0524$ & 0.0497 & 0.1 & 0 \\
\hline & $\mathrm{Cu}\left(\mathrm{mg} \mathrm{L}^{-1}\right)$ & $0.0136-0.0460$ & 0.0317 & 0.03 & 50 \\
\hline & $\mathrm{Zn}\left(\mathrm{mg} \mathrm{L}^{-1}\right)$ & $<0.0062-0.0232$ & 0.0109 & 0.2 & 0 \\
\hline & As $\left(\mu \mathrm{g} \mathrm{L}^{-1}\right)$ & $<2.1$ & 1 & 20 & 0 \\
\hline & $\mathrm{Ni}\left(\mu \mathrm{g} \mathrm{L}^{-1}\right)$ & $<3.6$ & I & 25 & 0 \\
\hline & $\mathrm{Pb}\left(\mu \mathrm{g} \mathrm{L}^{-1}\right)$ & $<2.1$ & 1 & 10 & 0 \\
\hline & $\mathrm{Cd}\left(\mu \mathrm{g} \mathrm{L}^{-1}\right)$ & $<0.14$ & 1 & 1 & 0 \\
\hline & $\mathrm{Cr}\left(\mathrm{mg} \mathrm{L}^{-1}\right)$ & $<0.0017$ & I & 0.05 & 0 \\
\hline & $\mathrm{Hg}\left(\mu \mathrm{g} \mathrm{L}^{-1}\right)$ & $<0.5$ & $<0.5$ & 0.3 & 0 \\
\hline & $\mathrm{SO}_{4}^{2-}\left(\mathrm{mg} \mathrm{L}^{-1}\right)$ & $21.6-29.6$ & 24.8 & 120 & 0 \\
\hline
\end{tabular}


Other two rivers have significantly lower values than MAC. The main way of pollution of these rivers is by spreading of dust from nearby flotation tailing in windy conditions. According to Romanian legislation for surface water, in considered rivers, the content for almost all of the analyzed elements is below the MAC [46] for this category of surface waters. The only exceptions are $\mathrm{Fe}$ and $\mathrm{Cu}$ which were with slightly increased concentrations probably because of windy weather before and during the sampling.

Maximum recorded concentration of iron was two times higher than MAC. Median value for Fe was below MAC for Bosneag River while for Nera River was two times higher but still with relatively low absolute concentrations. Possible reason for increased concentration of iron could be spreading of dust from nearby flotation tailing during windy weather. In recent researchers it was also noted that in general there are a trend of increasing of iron in river waters [48]. The possible causes of the increasing of $\mathrm{Fe}$ in the rivers are more elusive but probably also involve increased anaerobic microbial activity, considering the fact that water levels and temperature have increased during the period [49]. However, iron is not a strong hazardous element for human health, especially in recorded concentrations, but regarding of increased concentration it is expected that more attention will be given for clarification of noted increased transfer of Fe from soil to waters.

Increased copper concentrations were recorded in all considered rivers, with the highest content of $\mathrm{Cu}$ registered for Bosneag River, almost 4 times higher than MAC. However, median value was around 2 times higher than MAC. Having on mind that Bosneag River is closest to flotation tailing pond, probable reason for increased $\mathrm{Cu}$ concentration is spreading of dust from nearby flotation tailing during windy weather before and during sampling. Median value for $\mathrm{Cu}$ for Radimna River is 1.5 times higher than MAC and for Nera River is just slightly over MAC. These two rivers are located farther than Bosneag River from the flotation tailing which indicate similar reason for the measured $\mathrm{Cu}$ concentrations.

For the considered rivers on the Romanian side, it was important that no strong pollution with heavy metals was recorded. This is a consequence of the dominant dust pollution, and not AMD which is an incomparable higher danger than dust.

\section{CONCLUSIONS}

The present study is one of the broadest investigations of the multielement content in surface waters generated from copper mining activities in the cross-border region of Romania and Serbia. It may thus represent a reference point for observed concentrations in future studies on considered area. 
In Eastern Serbia, pH values for surface water samples from Bor city to the confluence of Bor and Timok River range from 1.77 to 7.72 indicating that most of the analyzed surface waters are strong acid water with $\mathrm{pH}$ values lower than 3.0. The recorded content of $\mathrm{Cd}, \mathrm{Mn}, \mathrm{Zn}$, and $\mathrm{Pb}$ is above the MAC in almost all of the analyzed samples. Considering recorded content, median value and percentage of samples with higher content than MAC, pollution main hazards are $\mathrm{Cd}, \mathrm{Mn}, \mathrm{Cu}, \mathrm{Fe}, \mathrm{Ni}, \mathrm{Zn}, \mathrm{Pb}$ and As. However, with addition consideration on pollutants impact on human health, the main risk is caused by $\mathrm{Cd}$, As, $\mathrm{Pb}$ and $\mathrm{Cu}$ pollution.

Samples from surface waters from rivers that belong to the III (Timok River) category show moderate pollution for the given category of surface waters. The manganese and sulphate content were exceeded in half of the analysed samples while nickel and cadmium exceeded in slightly higher percentage. The recorded concentrations of other considered elements were below the MAC values for this category of surface waters. Content of the main heavy metal polluter were dropped by increasing of distance from mining complex and by mixing of Bela River with Timok. However, based on recorded contents, on a longer distance from Bor mine, the main polluter were $\mathrm{Cd}$ and $\mathrm{Ni}$.

In samples that belong to II category surface waters (Danube) was detected increased values of manganese, cadmium, nickel, arsenic and sulphate. However, the maximum detected values of individual elements in these surface waters are not more than 2 times over the MAC for this category of surface water. Having on mind that median values for the most hazardous elements, As and Cd is below median value and with low absolute concentrations, these single results could not be considered as pollution indicator.

Decreases in the concentrations of $\mathrm{Fe}, \mathrm{Cu}, \mathrm{As}$, and $\mathrm{Pb}$ in surface river waters from confluence of Bela and Timok river were mainly due to precipitation of this metal ions on the river bed. On the other hand, $\mathrm{Cd}, \mathrm{Ni}$ and Mn stayed in increased concentrations even in III category surface waters indicating dilution of these elements and longer transportation by water ways.

Trends in concentrations of ions in surface waters of IV category in Eastern Serbia indicated that all considered heavy metals originate from a Bor mine and smelter as a main anthropogenic source.

Considered rivers on Romanian side, in Caras Severin County near Moldova Noua, do not have acidic character and there was not recorded strong pollution with heavy metals. Slightly raised concentrations were recorded only for iron and copper while slightly increased content of $\mathrm{SO}_{4}{ }^{2-}$ ions were recorded only in Bosneag River, probably as a consequence of vicinity to flotation tailing. 
Comparing pollution in rivers surrounding Moldova Noua in Romania where the largest environmental impact is spreading of the dust from flotation tailing and rivers surrounding Bor in Eastern Serbia with combined AMD, tailing leaking and dust spreading environmental impact, it is clear that strongest environmental impact on surface rivers have AMD. Moreover, due to mobility potential and water ways transportation of the diluted ions, AMD have the significant environmental impact on wider area, in case of Bor mine, on cross border area.

\section{EXPERIMENTAL SECTION}

Considered Romanian Serbian Cross border area is presented in Figure 7. Project includes area of mine Moldova Nouă from the Romanian side and Eastern Serbia area from the active copper mine in Bor, all the way to the confluence of the Timok into the Danube near Radujevac. This area was chosen because both mine locations have negative impact on surface water system which flow in both cases to Danube. Rivers Bosneag, Radimna and Nera from the Romanian side in Caras Severin County near Moldova Noua are also tributary of Danube River and flow in area which is affected by spreading of dust from the abandoned flotation tailing of copper mine. Bor, Krivelj, and Bela Rivers in Eastern Serbia belong to the watershed of Timok River, which is also a tributary of Danube River. All mentioned Rivers flow near to the largest mining complex in Republic of Serbia where mining activities continuously exist for more than 115 years.

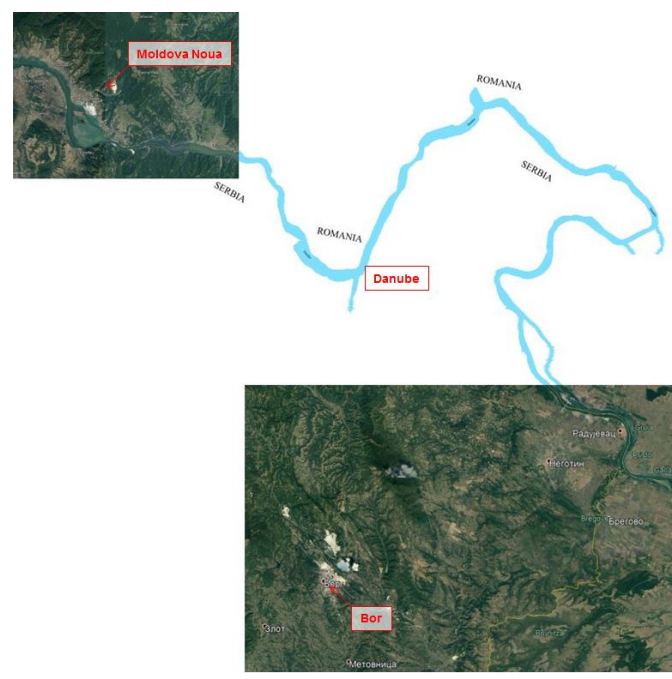

Figure 7. Romanian Serbian Cross border ROSNET2 Project area 
Sampling locations are presented on Figures 2 and 6. During sampling was recorded GPS data for each sampling point and noted: sampling method, time, air and water temperature, color and odor of water, redox potential, $\mathrm{pH}$ value, $\mathrm{DO}$ (dissolved oxygen) and electro conductivity. Before sampling of surface waters on site, all bottles for storing of samples were treated with $3 \% \mathrm{HNO}_{3}(30-40 \mathrm{ml})$ during 6 days. Surface water sampling was performed with containers (cans of $1 \mathrm{~L}$ ) which were rinsed three times in the river or water that will be sampling before sampling. One part of sample was poured into a container for measuring $\mathrm{pH}$ and temperature (also three times rinsed with water sample before performing measuring). After measuring the contents of containers were discarded. Other part of samples in quantity of exactly $50 \mathrm{ml}$ was poured by syringe in bottles which already contains $63 \%$ $2.5 \mathrm{ml} \mathrm{HNO}_{3}$, sealed and labelled. After packing, on site samples were transferred to chemical laboratory.

Samples were analyzed in chemical laboratory of Mining and Metallurgy Institute Bor with ICP-MS (Agilent Technologies 7700 Series, Singapore, Republic of Singapore); ICP-OES (Spectro Arcos, Kleve, Germany) and FIMS (Flow Injection Mercury System) 100 (Perkin Elmer, Norwalk, USA). Used techniques per elements with operating conditions are given in Table 3.

Table 3. Operating conditions for the analysis of the elements

\begin{tabular}{|c|c|c|c|}
\hline $\begin{array}{l}\text { Determined } \\
\text { elements }\end{array}$ & Technigue & Ope & ating conditions \\
\hline \multirow{5}{*}{$\mathrm{Hg}$} & \multirow{5}{*}{ FIMS-AAS } & Integration time (s) & 20 \\
\hline & & Data Processing & $\begin{array}{c}\text { Peak Height, Smoothing: } \\
0.5 \text { s or } 19 \text { points }\end{array}$ \\
\hline & & Lamp & $\mathrm{HCL}$ \\
\hline & & Slit (nm) & 0.7 \\
\hline & & Wavelength (nm) & 253.7 \\
\hline \multirow{9}{*}{$\begin{array}{c}\mathrm{Cr}, \mathrm{Cu}, \mathrm{Fe}, \mathrm{Mn}, \mathrm{S}, \\
\mathrm{Zn}\end{array}$} & \multirow{9}{*}{ ICPOES } & RF Power (W) & 1450 \\
\hline & & Coolant flow (L/min) & 13 \\
\hline & & Nebulizer flow (L/min) & 0.75 \\
\hline & & Auxiliary flow (L/min) & 1.0 \\
\hline & & Plasma, torch & $\begin{array}{c}\text { Quartz, demountable, } 2.0 \mathrm{~mm} \\
\text { injector tube }\end{array}$ \\
\hline & & Spray chamber & Scott \\
\hline & & Nebulizer & Cross-flow \\
\hline & & Sample aspiration rate & $2 \mathrm{~mL} / \mathrm{min}$ \\
\hline & & Wavelength (nm) & $\begin{array}{c}\text { Cr-267.716 nm; Cu-324.754 nm; } \\
\text { Fe-259.941; Mn-257.611; Mo- } \\
202.095 \text { nm; Se-196.090 nm; S- } \\
180.731 \text { nm; Zn-213.856 nm }\end{array}$ \\
\hline
\end{tabular}


STATE OF THE SURFACE WATERS IN CROSS BORDER REGION OF EASTERN SERBIA AND ...

\begin{tabular}{|c|c|c|c|}
\hline Determined & Technigue & \multicolumn{2}{|c|}{ Operating conditions } \\
\hline \multirow{9}{*}{ As, $\mathrm{Cd}, \mathrm{Ni}, \mathrm{Pb}$} & \multirow{9}{*}{ ICPMS } & RF Power (W) & 1550 \\
\hline & & RF matching (V) & 1.8 \\
\hline & & Sample depth (mm) & 10 \\
\hline & & Carrier gas (L/min) & 1.0 \\
\hline & & $\begin{array}{c}\text { Nebulizer pump speed } \\
(\mathrm{L} / \mathrm{min})\end{array}$ & 0.1 \\
\hline & & $\begin{array}{l}\text { Spray chamber } \\
\text { temperature }\left({ }^{\circ} \mathrm{C}\right)\end{array}$ & 2.0 \\
\hline & & Peak pattern (point) & 1.0 \\
\hline & & $\begin{array}{c}\text { Reaction gas cell flow } \\
(\mathrm{mL} / \mathrm{min})\end{array}$ & $\mathrm{He}-4.5$ \\
\hline & & Mass/Cell mode & $\begin{array}{c}\text { As-75 He; Cd-111-No gas; Ni-60-No } \\
\text { gas; Pb-208-No gas }\end{array}$ \\
\hline
\end{tabular}

ICP-OES surface waters analyses were performed according to (ISO 11885:2011) [50]. ICP-MS analysing were performed according to (ISO 17294:2016) [51].

The accuracy and the precision of the ICPMS and ICPOES methods were investigated analysing the two Standard Reference Material, NIST 1640a (Trace elements in natural water) and LGC Standard Reference Material VHG-QWPTM-15 (Water Pollution Trace metals). In Table 4 are given measured and certified concentrations with recovery rates for both used CRM.

Table 4. Measured and certified concentrations for both used CRM

\begin{tabular}{|c|c|c|c|c|c|c|c|c|}
\hline & \multicolumn{4}{|c|}{ NIST 1640a } & \multicolumn{4}{c|}{ VHG-QWPTM-15 } \\
\cline { 2 - 9 } Element & $\begin{array}{c}\text { Certifed } \\
\text { Value } \\
\left(\mu \mathrm{L} \mathrm{L}^{-1}\right)\end{array}$ & $\begin{array}{c}\text { Found } \\
\text { Value } \\
\left(\mu \mathrm{L} \mathrm{L}^{-1}\right)\end{array}$ & $\begin{array}{c}\mathrm{QC} \\
\text { Acceptance } \\
\text { Limits } \\
\left(\mu \mathrm{L} \mathrm{L}^{-1}\right)\end{array}$ & $\begin{array}{c}\text { Recovery } \\
(\%)\end{array}$ & $\begin{array}{c}\text { Certifed } \\
\text { Value } \\
\left(\mu \mathrm{L}^{-1}\right)\end{array}$ & $\begin{array}{c}\text { Found } \\
\text { Value } \\
\left(\mu \mathrm{L}^{-1}\right)\end{array}$ & $\begin{array}{c}\text { QC } \\
\text { Acceptance } \\
\text { Limits } \\
\left(\mu \mathrm{L}^{-1}\right)\end{array}$ & $\begin{array}{c}\text { Recovery } \\
(\%)\end{array}$ \\
\hline $\mathrm{As}$ & 8.075 & 11.350 & \pm 0.070 & 140.6 & 516 & 497 & $451-568$ & 96.3 \\
\hline $\mathrm{Cd}$ & 3.992 & 3.980 & \pm 0.074 & 99.7 & 212 & 211 & $188-227$ & 99.6 \\
\hline $\mathrm{Cr}$ & 40.54 & 47.67 & \pm 0.30 & 117.6 & 113 & 112 & $103-123$ & 99.1 \\
\hline $\mathrm{Cu}$ & 85.75 & 110.82 & \pm 0.51 & 129.2 & 132 & 140 & $120-144$ & 106.1 \\
\hline $\mathrm{Fe}$ & 36.8 & 39.3 & \pm 1.8 & 106.8 & 3400 & 3514 & $3080-3770$ & 103.4 \\
\hline $\mathrm{Pb}$ & 12.101 & 11.421 & \pm 0.050 & 94.4 & 993 & 1008 & $899-1080$ & 101.6 \\
\hline $\mathrm{Mn}$ & 40.39 & 44.86 & \pm 0.36 & 111.1 & 1790 & 1769 & $1660-1970$ & 98.8 \\
\hline $\mathrm{Mo}$ & 45.60 & 44.92 & \pm 0.61 & 98.6 & 141 & 139 & $127-152$ & 98.6 \\
\hline $\mathrm{Ni}$ & 25.32 & 29.00 & \pm 0.14 & 114.6 & 630 & 617 & $572-687$ & 97.9 \\
\hline $\mathrm{Se}$ & 20.13 & 20.70 & \pm 0.17 & 102.8 & 440 & 424 & $458-582$ & 96.4 \\
\hline $\mathrm{Zn}$ & 55.64 & 51.27 & \pm 0.35 & 92.1 & 485 & 476 & $438-534$ & 98.1 \\
\hline
\end{tabular}


As shown in Table 4, the measured values and the certified values are in good agreement for all the certified concentrations for SRM LGC VHGQWPTM-15. The Recovery for SRM NIST 1640a for As, Cd, Ni and Pb lies in the range $94.4-140.6 \%$.

After chemical analyses, results were used for further calculations and environmental evaluation. Sample residues were stored in Mining and Metallurgy Institute Bor.

\section{ACKNOWLEDGMENTS}

This work was financially supported by the EU under Interreg - IPA CBC Romania-Serbia Programme and co-financed by the partner states in the Programme. Project ROmania Serbia NETwork for assessing and disseminating the impact of copper mining activities on water quality in the cross-border area (RoS-NET2) eMS code RORS - 337. The authors are also grateful for funding by Ministry of Education, Science and Technological Development Serbia, by Registration No. 451-03-9/2021-14/200052

\section{REFERENCES}

1. Đorđijevski S.; Ishiyama D.; Ogawa Y.; Stevanović Z.; Environ Sci Pollut R, 2018, 25(25), 25005-25019.

2. Johnson D.B.; Hallberg K.B.; Sci Tot Environ, 2005, 338, 3-14.

3. Nordstrom D.K.; Alpers C.N.; Proc Natl Acad Sci USA, 1999, 96(7), 3455-3462.

4. Blowes T.A.; Jambor D.W.; Scott J.L.; Can Geotech J, 1994, 31, 502-512.

5. Azapagic A.; J Clean Prod, 2004, 12, 639-662.

6. ICME and UNEP; Case Studies on Tailings Management. International Council on Metals and the Environment and United Nations Environment Programme 1998, 1998, p.58.

7. Akcil A.; Koldas S.; J Clean Prod, 2004, 14, 1139-1145.

8. Charbonier B.; Management of mining, quarrying, and ore-processing waste in the European Union 2001, BRGM, 2001, 29.

9. Dimitrijević M.D.; Bakar, 2012, 37 (1), 33-44.

10. lakovleva, E. Mäkilä; Salonen E.; Sitarz M.; Wang S.; Sillanpää, M.; Ecol Eng, 2015, 81, 30-40.

11. Stevanović Z.; Obradović Lj.; Marković R.; Jonović R.; Avramović Lj.; Bugarin M.; Stevanovic J.; Waste Water - Treatment Technologies and Recent Analytical Developments, Fernando Sebastian García, Einschlag and Luciano Carlos, IntechOpen, London, 2013, DOI: 10.5772/51902.

12. Zobrist J.; Sima M.; Dogaru D.; Senila M.; Yang H.; Popescu C.; Roman C.; Bela A.; Frei L.; Dold B.; Balteanu D.; Environ Sci Pollut R, 2009, 16, 14-26. 
13. Markovic Z.S.; Environmental and Food Safety and Security for South-East Europe and Ukraine, Vitale K., Springer, Dnepropetrovsk, Ukraine, 2011, 129-136.

14. Moldova Noua Mine;

15. Popescu F.; Proc Technol, 2016, 22, 440-444.

16. Dimitrijević M.D.; Antonijević M.M.; Dimitrijević V.Lj.; Hem Ind, 2002, 56, 299-316.

17. Abraitis P.K.; Pattrick R.A.D.; Vaughan D.J.; Int J Miner Process, 2004, 74, 41-59.

18. Gorgievski M.; Božić D.; Stanković V.; Bogdanović G.; J Hazard Mater, 2009, 170, 716-721.

19. Wang A.; Zhou K.; Zhang X.; Zhou D.; Peng C.; Chen W.; Chem Eng J, 2019, 373, 23-30.

20. R. Markovic; M. Bessho; N. Masuda; Z. Stevanovic; D. Bozic; T. Apostolovski Trujic; V. Gardic; Appl. Sci., 2020, 10(17), 5925.

21. Regulation on hazardous substances in waters ("Offic. Gaz. SRS", 31/82).

22. Lyn P.; Altern Med Rev, 2003, Vol.8, Issue 2, 106-128.

23. Jordan E.; Combined Sewer Overflow Toxic Pollutant Study, U.S. Environmental Protection Agency, Washington, USA, 1984, 60-67.

24. Goovaerts P.; Encyclopedia of Environmental Health, Ed. J.O. Nriagu, Elsevier: Amsterdam, Nederland, 2011, 701-714.

25. Mahmood Q.; Mahnoor A.; Shahreen S.; Hayat M.T.; Ali S.; Cadmium Toxicity and Tolerance in Plants, Ed. Hasanuzzaman M.; Vara M.N., Elsevier: Amsterdam, Nederland, 2019, 141-161.

26. Aoshima K.; J Soil Sci Plant Nutr, 2016, 62, 319-26.

27. Pan J.L.; Plant J.A.; Voulvoulis N.; Oates C.J.; Ihlenfeld C.; Environ Geochem HIth, 2010, 32, 1-12.

28. Chunhabundit R.; Toxicol Res, 2016, 32(1), 65-72.

29. Khan M.A.; Khan S.; Khan A.; Alam M.; Sci Total Environ, 2017, 601, 15911605.

30. Tabassum R.A.; Shahid M.; Dumat C.; Environ Sci Pollut Res, 2019, 26, 20018-20029.

31. U.S. Environmental Protection Agency; Integrated Risk Information System (IRIS) on Arsenic, National Center for Environmental Assessment, Office of Research and Development, Washington, DC. 1998.

32. Watanabe T.; Hirano S.; Arch Toxicol, 2013, 87, 969-979.

33. Ebert F.; Weiss A.; Bültemeyer M.; Hamann I.; Hartwig A.; Schwerdtle T.; Mutat Res, 2011, 715, 32-41.

34. Wani A.L.; Anjum A.; Usmani J.A.; Interdiscip Toxicol, 2015, 8(2), 55-64.

35. Meyer P.A.; Brown M.J.; Falk H.; Mutat Res, 2008, 659(1-2), 166-175.

36. Nasiruddin R.M.; Tangpong J.; Rahman M.; Toxicol Rep, 2018, 704-713.

37. Dórea J.G.; Environ Res, 2019, 177:108641.

38. Bikash D.; Singh W.S.; Manna K.; Indian J. Medical Spec, 2019, 10(2):66.

39. Kwon S.Y.; Bae O.N.; Noh J.Y.; Kim K.; Kang S.; Shin Y.J.; Environ Health Perspect, 2015, 123:120-7.

40. Vigeh M.; Smith D.R.; Hsu P.C.; Iran J Reprod Med, 2011, 9:1-8.

41. Bhardwaj P.; Rai D.V.; Int J Res Med Sci, 2016, 4:177-80.

42. Gillis B.S.; Arbieva Z.; Gavin I.M.; BMC Genomics, 2012, 13:344. 
43. Harris Z.L.; Gitlin J.D.; Am J Clin Nutr, 1996, 63, 836S-841S.

44. Sánchez-Rodas D.; Sánchez de la Campa M.; de la Rosa Jesus A.D.; Oliveira V.; Gómez-Ariza J.L.; Querol X.; Alastuey A; Chemosphere, 2007, 66, 14851493.

45. Kovacevic R.; Jovasevic-Stojanovic M.; Tasic V.; Milosevic N.; Petrovic N.; Stankovic S.; Matic-Besarabic S.; Chem Ind Chem Eng Q - CICEQ, 2010, 16, 269-279.

46. The Romanian Ministry of Environment and Water Management. Order no $161 / 2006$ for the approval of the Normative on the Classification of Surface Water Quality to establish the ecological status of the water bodies. Official Journal of Romania, No. 11/13.06.2006 (in Romanian).

47. Ostafe V.; Stevanovic Z.; Popovici Sturza C.; Isvoran A.; New Front Chem, 2021, 30(1), 1-7.

48. Ekstrom A.A.; Regnell O.; Reader H.E.; Anders Nilson P.; Lofgren S.; Kritzberg E.; J Geophys Res-Biogeo, 2016, Vol.121(2), 479-493.

49. Sarkkola S.; Nieminen H.; Koivusalo A.; Laurén P.; Kortelainen T.; Mattsson M.; Palviainen S.; Piirainen M.; Finer L.; Sci. Total Environ., 2013, 463-464.

50. Water quality - Determination of selected elements by inductively coupled plasma optical emission spectrometry (ICP-OES) (ISO 11885:2011).

51. Water quality - Application of inductively coupled plasma mass spectrometry (ICP-MS) (ISO 17294:2016). 